\title{
Bilateral Parotid Enlargement Following Hematotoxic Snake Bite: A Unusual Sequelae of the Venomous Sting
}

\author{
Sivaraman, ${ }^{1}$ Maniram Kumhar, ${ }^{* 2}$ Priti Kalyana, ${ }^{1}$ Ramkishore Roat $^{1}$
}

\section{INTRODUCTION}

Snake bite is a neglected tropical disease of global importance. India has the highest number of deaths (35,000-50,000 people dying per year) due to snakebites. ${ }^{1}$ Common venomous snakes in India are common cobra (Najanaja), saw scaled viper (Echiscarinatus), Russell's viper (Daboia russelii) and krait (Bungarus caeruleus). Daboia is one of the most common species responsible for causing the most snake bite incidents and deaths among all venomous snakes on account of many factors, such as their wide distribution, aggressive response to host, and frequent occurrence in dense populated areas. Development of parotid swelling after snake bite is a rare entity. The number of case reports from India documenting such as unusual complication were very few. The published data documenting parotid enlargement even in world literature are limited. ${ }^{2}$ So we are reporting a case with bilateral parotid gland enlargement following snake envenomation for its rarity.

\section{CASE REPORT}

Sivaraman, ${ }^{1}$ Maniram Kumhar, ${ }^{* 2}$ Priti Kalyana, ${ }^{1}$ Ramkishore Roat ${ }^{1}$

'Postgraduate Resident, Department of General, Medicine, JLN Medical College, Ajmer, Rajasthan, India

2Professor, Department of General, Medicine, JLN Medical College, Ajmer, Rajasthan, India

Correspondence

Dr. Maniram Kumhar

Professor Department of general

medicine JLN medical college Ajmer,

Rajasthan, India.

Ph.no: 9460610416

Email: pysira@gmail.com

History

- Submission Date: 20-03-16

- Revised Date: 25-10-16

- Accepted Date: 04-11-16

DOI : 10.5530ijmedph.2017.1.12

Article Available online

http://www.ijmedph.org/v7/i1

Copyright

(C) 2017 Phcog.Net. This is an openaccess article distributed under the terms of the Creative Commons Attribution 4.0 International license. ish red discoloration in left side of the face. USG of parotid region showed enlargement of parotid gland with left side measuring $57 \mathrm{~mm} \mathrm{x} 44 \mathrm{~mm}$ and right side measuring $55 \times 42 \mathrm{~mm}[\mathrm{~L}>\mathrm{R}]$ (Figure 2). Other salivary glands were not enlarged. There was no enlargement of any cervical group lymph nodes. Lab investigations showed mildly deranged liver function test with slightly prolonged SGOT and SGPT. WBCT was more than 20 min even after 12 hour of admission. BT, PT and APTT were mildly prolonged. ASV was readministered. Injection vitamin $\mathrm{K}$ and Fresh frozen plasma were given.

Patient was kept on continuous monitoring and all parameters were frequently rechecked and the patient was gradually improving and she was discharged on $8^{\text {th }}$ post admission day.

\section{DISCUSSION}

Snake bite is one of the important cause of accidental death in rural india. The clinical features of viper bite may vary from minor local symptoms to life threatening systemic manifestations. Envenoming due to viper bites results in tissue damage, characterized by swelling and blistering at the bite site. Viper venom can also induce coagulopathy.

A study conducted by Monteiro et al. from Southern India showed that local signs of envenomation was present in $96 \%$ cases of viper bite, while systemic signs of envenomation was present in $90 \%$ of cases. ${ }^{3}$

Other than these usual clinical features, following snake bite patients may present with unusual complications such as hypopituitarism, encephalopathy, cerebral infarct, optic neuritis and myocardial infarction may occur. ${ }^{4}$ Bilateral parotid swelling is an unusual clinical feature of viper bite. A similar case of bilateral parotid swelling after Russel viper bite was reported by Chakraborty et al and Deepak et al.,25 Their patient developed parotid swelling about 8 hours and 6 hours after snake bite respectively.

Exact cause of parotid enlargement after snake bite is unknown. But this unusual manifestation has been documented in the Indian National Snakebite Protocol 2007. More studies need to be done to determine the exact pathogenesis of parotid enlargement following snake bite. 


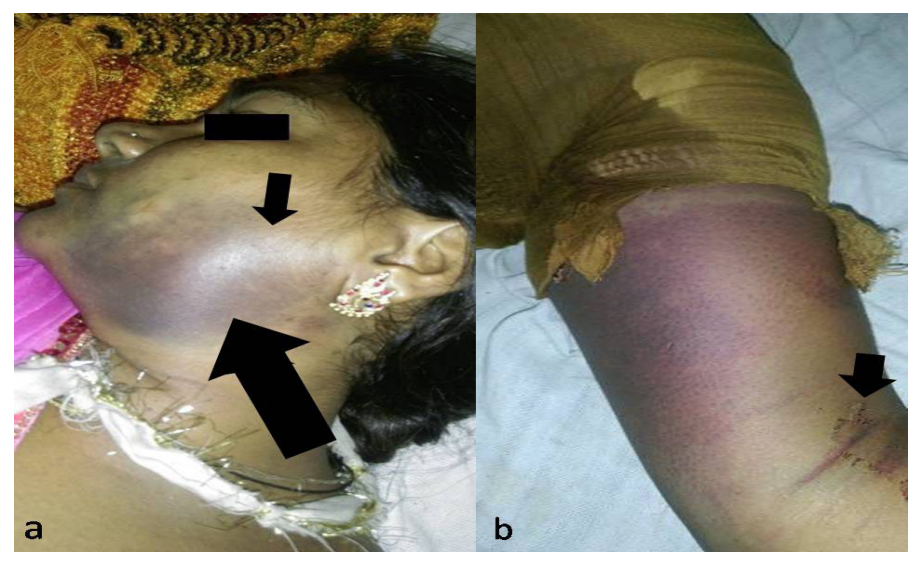

Figure 1(a): Arrow showing left side parotid gland enlargement with bluish red discolouration of overlying skin. Figure $\mathbf{1}$ (b): Arrow showing site of bite

\section{CONCLUSION}

Bilateral parotid enlargement after snake bite is a rare entity and these rare presentations of some dangerous envenomation may give vital clue about the underlying complications and organ involvement and help to sense the prognosis of the patient.

\section{ACKNOWLEGEMENT}

\section{CONFLICT OF INTEREST}

There is no conflict of interest

\section{REFERENCES}

1. Warrell DA. The clinical management of snake bites in the Southeast Asian region. Southeast Asian J Trop Med Public Health. 1999;30(1):1-

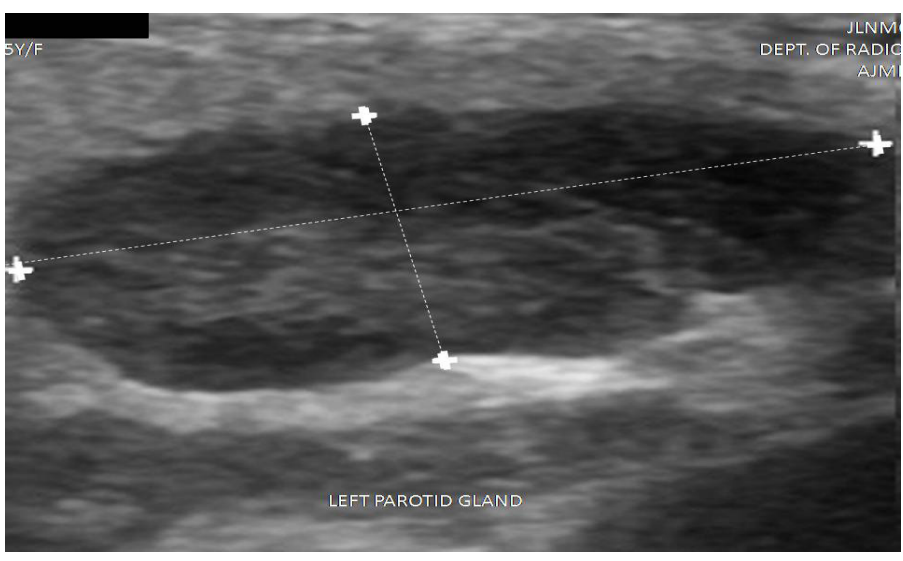

Figure $\mathbf{2}$ : Showing USG of the patient with left parotid gland enlargement with homogeneous to slightly hyperechoic echogenecity

84.

2. Deepak M, Basavaprabhu A, Ramapuram JT, Nithyananda C, Mahalingam S. Bilateral parotid enlargement following snake bite: A rare sign. Asian Pacific Journal of Tropical Biomedicine. 2013;3(2):154-5. http:// dx.doi.org/10.1016/S2221-1691(13)60041-6.

3. Monteiro FN, Kanchan T, Bhagavath P, Kumar GP, Menezes RG, Yoganarasimha K. Clinico-epidemiological features of viper bite envenomation: a study from Manipal, South India. Singapore Med J. 2012;53(3):203. PMid:22434296.

4. Antonypillai CN, Wass JA, Warrell DA, Rajaratnam HR. Hypopituitarism following envenoming by Russell's vipers (Daboia siamensis and D. russelii) resembling Sheehan's syndrome: first case report from Sri Lanka, a review of the literature and recommendations for endocrine management. QJM. 2010;104(2):97-108. http://dx.doi.org/10.1093/ qjmed/hcq214; PMid:21115460.

5. Chakraborty PP, Bhattacharjee R. Bilateral parotid swelling: an unusual complication of viper bite. J Assoc Physicians India. 2010;58:460 PMid:21125718.

Cite this article : Sivaraman, Kumhar M, Kalyana P, Roat RK. Bilateral Parotid Enlargement Following Hematotoxic Snake Bite: A Unusual Sequelae of the Venomous Sting. Int J Med. Public Health. 2017; 7(1): 66-7 